\title{
Re-thinking the Potential for Airborne Transmission of SARS-CoV-2
}

Joseph G. Allen and Linsey C. Marr

Joseph G. Allen, Doctor of Science (DSc), Master of Public Health (MPH)

Department of Environmental Health

Harvard T.H. Chan School of Public Health

401 Park Drive, 404-L

Boston, MA 02215

617-384-8475

jgallen@hsph.harvard.edu

Linsey C. Marr, Doctor of Philosophy (PhD)

Department of Civil and Environmental Engineering

Virginia Tech

1145 Perry St. (0246)

Durham 411

Blacksburg, VA 24061

540-231-6071

Imarr@vt.edu 


\title{
Re-Thinking the Potential for Airborne Transmission of SARS-CoV-2
}

\author{
Joseph G. Allen ${ }^{1}$ and Linsey C. Marr ${ }^{2}$ \\ ${ }^{1}$ Healthy Buildings Program, Department of Environmental Health, Harvard T.H. Chan School of \\ Public Health, Boston, MA, USA \\ ${ }^{2}$ Department of Civil and Environmental Engineering, Virginia Tech, Blacksburg, VA, USA
}

Evidence for the potential for airborne transmission of SARS-CoV-19 continues to accumulate, with important implications for healthcare workers, as well as the general public. Three lines of evidence support this conclusion.

\section{Detection and survival of coronavirus in air}

SARS-CoV-2 viral RNA in air has been detected in several studies in hospitals, including at distances greater than $2 \mathrm{~m}$ from patients and in outdoor air in crowded areas near a hospital and a department store. ${ }^{\text {ii }}{ }^{\text {iii }}$ One study found that the majority of these viruses were associated with aerosols (i.e., microscopic droplets) of diameter 2.5 microns and smaller, which can remain suspended in air for 2 hours or more. 'Another detected SARS-CoV-2 in aerosols in the size range of 1-4 microns. iii Furthermore, viral RNA has been detected on the surfaces of an air exhaust outlet and fan, places where direct transfer from an infected person could not occur. ${ }^{\text {iv }}$ While these studies assayed viral RNA, the finding that SARS-CoV-2 in fine aerosols $(<5$ microns) has a half-life of 1 hour in terms of infectivity raises the possibility that some airborne virus is infectious. ${ }^{v}$ If we assume that SARS-CoV-2 survives in large droplets, there is no reason to think that the virus would not also survive in aerosols. Previous studies have shown that other viruses survive equally well, if not better, in suspended aerosols compared to large, stationary droplets. ${ }^{\text {vi vii viii }}$

\section{Asymptomatic Infectivity}

There are reports of asymptomatic transmission of SARS-CoV-2. ${ }^{i x}$ By definition, asymptomatic patients are not coughing or sneezing, which means they are not frequently generating large droplets. Therefore, for these asymptomatic patients, other modes of transmission, namely fomite and airborne, must be occurring. Studies on patients with confirmed influenza infection, show that infectious virus in fine particles can be released by regular breathing and talking, without coughing. ${ }^{\mathrm{x}}$ This is of concern because a new preprint shows high shedding of infectious SARS-CoV-2 in the throat pre-symptoms. ${ }^{\mathrm{xi}}$

\section{Aerosol physics}

While the traditional distinction between "droplet" and "airborne" transmission of infectious disease has been useful for setting guidelines on the use of personal protective equipment, it has also established a false dichotomy in understanding the behavior of viruses in the air. Viruscontaining droplets that are released by breathing, talking, and coughing span a continuum of sizes, from 0.01 to hundreds of microns. It is impossible for someone to release "large droplets" (>5 microns) without also releasing smaller ones. ${ }^{\text {xii }}$ Thus, transmission that is purported to occur via the spray of large droplets from a cough could in fact be occurring through inhalation of 
much smaller droplets at close range. In fact, a physics-based simulation suggests that the majority of exposure at close range occurs by inhalation of small droplets rather than by contact with large droplets that land on the mouth, nose, and eyes, unless the people are closer than 30 $\mathrm{cm}$ or the droplets are very large. ${ }^{\text {xii }}$

\section{Conclusion and Implications}

Evidence is emerging indicating that, in addition to transmission via large droplets and fomites, SARS-CoV-2 is also transmitted via airborne particles. Recognition of this transmission route is critically important because healthcare workers are experiencing high rates of infection. A shortage of N95 respirators and other personal protective equipment, and lack of administrative and engineering controls addressing airborne exposure, may be contributing factors. More comprehensive guidance on how to protect healthcare workers and the general public should be considered in light of this new scientific evidence.

\section{Funding and Disclosure}

The authors do not have a funding source for this article and declare no competing interests.

\footnotetext{
${ }^{\text {i }}$ Liu Y, Ning Z, Chen Y, Guo M, Liu Y, Gali NK, Sun L, Duan Y, Cai J, Westerdahl D, Liu X, 2020. Aerodynamic analysis of SARS-CoV-2 in two Wuhan hospitals. Nature, https://doi.org/10.1038/s41586-020-

2271-2273.

ii Santarpia JL, Rivera DN, Herrera V, Morwitzer MJ, Creager H, Santarpia GW, Crown KK, Brett-Major D, Schnaubelt E, Broadhurst MJ, Lawler JV, 2020. Transmission potential of SARS-CoV-2 in viral shedding observed at the University of Nebraska Medical Center. medRxiv, https://www.medrxiv.org/content/10.1101/2020.03.23.20039446v2.

iii Chia PY, Coleman KK, Tan YK, Ong SWX, Gum M, Lau SK, Sutjipto S, Lee PH, Young BE, Milton DK, Gray GC, 2020. Detection of air and surface contamination by Severe Acute Respiratory Syndrome Coronavirus 2

(SARS-CoV-2) in hospital rooms of infected patients. medRxiv, https://www.medrxiv.org/content/10.1101/2020.03.29.20046557v2.

iv Ong SW, Tan YK, Chia PY, Lee TH, Ng OT, Wong MS, Marimuthu K, 2020. Air, surface, environmental, and personal protective equipment contamination by Severe Acute Respiratory Syndrome Coronavirus 2 (SARS-CoV-2) from a symptomatic patient. JAMA, 323(16):1610-1612.

${ }^{v}$ van Doremalen N, Bushmaker T, Morris DH, Holbrook MG, Gamble A, Williamson BN, Tamin A, Harcourt JL, Thornburg NJ, Gerber SI, Lloyd-Smith, JO, 2020. Aerosol and surface stability of SARS-CoV-2 as compared with SARS-CoV-1. New England Journal of Medicine, 382:1564-1567.

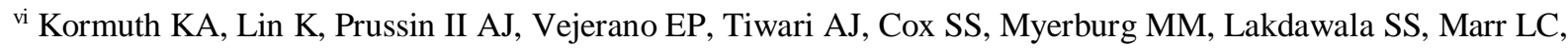
2018. Influenza virus infectivity is retained in aerosols and droplets independent of relative humidity. Journal of Infectious Diseases, 218(5):739-747.

vii Kormuth KA, Lin K, Qian Z, Myerburg MM, Marr LC, Lakdawala SS, 2019. Environmental persistence of influenza viruses is dependent upon virus type and host origin. mSphere, 4:e00552-19.

viii Lin K, Marr LC, 2020. Humidity-dependent decay of viruses, but not bacteria, in aerosols and droplets follows disinfection kinetics. Environmental Science \& Technology, 54(2):1024-1032.

ix Li C, Ji F, Wang L, Wang L, Hao J, Dai M, et al. Asymptomatic and human-to-human transmission of SARSCoV-2 in a 2-family cluster, Xuzhou, China. Emerg Infect Dis. 2020 Jul [cited April 11, 2020]. https://doi.org/10.3201/eid2607.200718

${ }^{x}$ Yan J, Grantham M, Pantelic J, de Mesquita PJ, Albert B, Liu F, Ehrman S, Milton DK, EMIT Consortium, 2018. Infectious virus in exhaled breath of symptomatic seasonal influenza cases from a college community. Proceedings of the National Academy of Sciences, 115(5):1081-1086.
} 


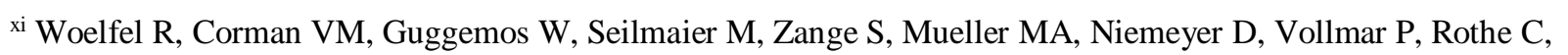
Hoelscher M, Bleicker T, 2020. Clinical presentation and virological assessment of hospitalized cases of coronavirus disease 2019 in a travel-associated transmission cluster. medRxiv, https://www.medrxiv.org/content/10.1101/2020.03.05.20030502v1.

xii Johnson GR, Morawska L, Ristovski ZD, Hargreaves M, Mengersen K, Chao CY, Wan MP, Li Y, Xie X, Katoshevski D, Corbett S., 2011. Modality of human expired aerosol size distributions. Journal of Aerosol Science, 42(12):839-851.

xiii Chen W, Zhang N, Wei J, Yen H, Li Y., 2020. Short-range airborne route dominates exposure of respiratory infection during close contact. Building and Environment, 176:106859. 